Dwie ciąże pojedyncze u chorej na fenyloketonurię (p.R408W/p.R408W) na diecie niskofenyloalaninowej zakończone urodzeniem zdrowego potomstwa - powtarzalny brak oczekiwanego znaczącego wzrostu tolerancji fenyloalaniny w III trymestrze ciąży

\title{
Two singleton pregnancies of phenylketonuric woman (p.R408W/p.R408W) on low phenylalanine diet resulting in healthy offspring: A recurrent lack of expected meaningful increase in phenylalanine tolerance during the third trimester
}

\author{
Joanna Żółkowska1,A-D,F, Kamil Konrad Hozyasz 2,A,C,E,F \\ ${ }^{1}$ Przykliniczna Poradnia Fenyloketonurii, Instytut Matki i Dziecka, Warszawa, Polska \\ 2 Państwowa Szkoła Wyższa im. Papieża Jana Pawła II w Białej Podlaskiej, Biała Podlaska, Polska \\ A - koncepcja i projekt badania, B - gromadzenie i/lub zestawianie danych, C - analiza i interpretacja danych, \\ D - napisanie artykułu, E - krytyczne zrecenzowanie artykułu, F- zatwierdzenie ostatecznej wersji artykułu
}

\section{Adres do korespondencj \\ Kamil Konrad Hozyasz}

e-mail: khozyasz@verco.com.pl

\section{Zewnętrzne źródła finansowania} Brak

Konflikt interesów

Nie występuje

Praca wpłynęła do Redakcji: $10.09 .2018 \mathrm{r}$.

Po recenzji: 19.11.2018 r.

Zaakceptowano do druku: 11.12.2018 r.

Cytowanie

Żółkowska J, Hozyasz KK. Dwie ciąże pojedyncze u chorej na fenyloketonurię (p.R408W/p.R408W) na diecie niskofenyloalaninowej zakończone urodzeniem zdrowego potomstwa - powtarzalny brak oczekiwanego znaczącego wzrostu tolerancji fenyloalaniny w III trymestrze ciąży Piel Zdr Publ. 2019;9(2):147-153. doi:10.17219/pzp/100660

D01

10.17219/pzp/100660

Copyright

๑) 2019 by Wroclaw Medical University

This is an article distributed under the terms of the

Creative Commons Attribution Non-Commercial License

(http://creativecommons.org/licenses/by-nc-nd/4.0/)

\section{Streszczenie}

Duże stężenia Phe w ciąży są przyczyną MPKU (upośledzenie umysłowe, małogłowie, wady wrodzone), któremu można zapobiec, stosując terapię dietą niskofenyloalaninową. Autorzy niniejszego artykułu przedstawili 2 ciąże pojedyncze (zakończone urodzeniem zdrowego potomstwa) pacjentki chorej na PKU, która pozostawała w stanie wyrównania metabolicznego zarówno w okresie prekoncepcyjnym, jak i będąc w ciąży. W praktyce klinicznej ocena tolerancji Phe opiera się na częstych oznaczeniach stężenia tego aminokwasu w powiązaniu z analizą jadłospisu. Zgodnie z danymi z piśmiennictwa autorzy oczekiwali znaczącego wzrostu tolerancji Phe w III trymestrze, gdyż jego brak uważa się za marker tej choroby także u płodu. Analizując wyniki badań pacjentki, zaobserwowano, że w pierwszej i drugiej ciąży tolerancja Phe w III trymestrze i podczas całej ciąży wzrosła odpowiednio $0453 \mathrm{mg}$ (30,2\%)/1653 mg (551\%) i $200 \mathrm{mg}$ (12,5\%)/1560 mg (650\%). Wzorzec zmian tolerancji Phe był podobny tylko w drugiej połowie obu ciąż. Niezbędne są dalsze badania nad czynnikami wpływającymi na homeostazę Phe w ciąży u chorych na fenyloketonurię.

Słowa kluczowe: zdrowie publiczne, fenyloketonuria, tolerancja fenyloalaniny, oddziaływania matczyno-płodowe 


\section{Abstract}

The maternal phenylketonuria (PKU) syndrome is caused by high phenylalanine (Phe) level during pregnancy. Dietary treatment to control Phe concentration (lowPhe diet) can prevent sequelae like intellectual disability, microcephaly and birth defects. In this study, 2 singleton pregnancies resulting in healthy offspring in one woman with phenylketonuria are reported. A state of metabolic control was sustained both during the preconception period and pregnancy in the course of both pregnancies. In clinical practice, the empirical determination of Phe tolerance relies on frequent assessment of blood Phe concentrations in patients with PKU in relation to Phe intake assessed using food records. In contrast to predictions based on literature data stating that Phe tolerance intensively increases in the third trimester and a low Phe tolerance may indicate fetal PKU, Phe tolerance in both pregnancies showed a low increase in the third trimester and a more noticeable increase during the whole pregnancy: $453 \mathrm{mg}(30.2 \%) / 1653 \mathrm{mg}(551 \%)$ and $200 \mathrm{mg}$ (12.5\%)/1560 mg (650\%), respectively. Interestingly, the patterns of Phe increase were relatively similar only in the second half of pregnancy. Further research on determinants of Phe tolerance in pregnant women with PKU is needed.

Key words: public health, phenylketonuria, phenylalanine tolerance, maternal-fetal interactions

The benefits of newborn PKU screening and treatment could be significantly curtailed if adequate resources, education, and funding are not available to follow and monitor women with PKU and their babies.

\section{Robert Resta ${ }^{1}$}

\section{Wprowadzenie}

Wykrycie przypadku fenyloketonurii klasycznej (ang. phenylketonuria - PKU) w populacyjnym badaniu przesiewowym noworodków i wdrożenie diety niskofenyloalaninowej jest powiązane z ryzykiem wystąpienia zespołu fenyloketonurii matczynej (ang. maternal phenylketonuria - MPKU) u potomstwa pacjentki rezygnującej z leczenia dietetycznego po osiągnięciu dorosłości. W niesprzyjających okolicznościach może dojść do zastąpienia jednego problemu zdrowotnego innym - chora na PKU kobieta, u której zapobiegnięto ograniczeniu rozwoju intelektualnego i fizycznego wykluczającym rozród, wydaje na świat chore potomstwo wskutek narażenia na teratogenne działanie wysokich stężeń aminokwasu fenyloalaniny (Phe). ${ }^{1-3}$ Obecnie wiemy, że po zaniechaniu leczenia przez pacjentkę dieta z ograniczoną podażą Phe powinna być ponownie rygorystycznie wdrożona w okresie prekoncepcyjnym i stosowana pod nadzorem lekarza i dietetyka przez całą ciążę. ${ }^{4-6}$ Podaż Phe zwiększa się bowiem błyskawicznie, gdy stężenie tego niezbędnego aminokwasu osiąga wartość poniżej 120 mmol/l (2 mg\%) we krwi ciężarnej. ${ }^{6}$ Ogólne zasady zapobiegania MPKU są powszechnie znane, przy czym brakuje szczegółowych analiz dotyczących prognozowania wzrostu tolerancji Phe u ciężarnych, a niektóre wskazania wymagają krytycznej oceny, ${ }^{5,7}$ gdyż, jak pokazują badania doświadczalne na zwierzętach, restrykcje dietetyczne mogą mieć bardzo zróżnicowane następstwa u potomstwa. ${ }^{8}$ Chęć poznania optymalnego, ze względu na chorobę, prekoncepcyjnego wskaźnika masy ciała (ang. body mass index - BMI) u pacjentek nie stanowiła dotychczas podmiotu analiz, ${ }^{6}$ pomimo identyfikacji fizjologicznych zależności między BMI ciężarnej a kształtowaniem się metabolizmu płodu ${ }^{9,10}$ oraz wpływu glikemii na transfer łożyskowy. ${ }^{11}$ Zaburzony matczyny metabolizm Phe przypuszczalnie uzyskuje znaczące wsparcie z dojrzewającej wątroby płodu. ${ }^{7}$ W 2009 r. Kohlschütter et al. ${ }^{7}$ zwrócili uwagę, że brak oczekiwanego wzrostu tolerancji Phe w III trymestrze może być markerem wystąpienia PKU także u płodu, którą to obserwację popularyzują najnowsze europejskie rekomendacje dotyczące diagnozowania i leczenia tej choroby. ${ }^{6} \mathrm{U}$ opisanych przez Kohlschütter et al. ${ }^{7} 2$ prawidłowo leczonych kobiet chorych na PKU (genotypy: p.194del/p.P281L i p.165T/ p.R408W) tolerancja Phe wzrosła w III trymestrze ciąży z nieobciążonym chorobą płodem o 100\% (900 mg) i 50\% (500 mg).

Celem pracy było przedstawienie 2 ciąż u chorej na PKU (stosującej dietę niskofenyloalaninową z dobrym rezultatem), w których nie nastąpił radykalny wzrost tolerancji Phe pod koniec każdej z nich.

\section{Opis przypadku}

U pacjentki rozpoznano PKU klasyczną i wdrożono leczenie dietetyczne w okresie noworodkowym. Kobieta ukończyła szkołę zawodową i technikum uzupełniające dla osób dorosłych. W wieku 23 lat zawarła związek małżeński. Nie przeszła poronień. Do ciąży pierwszej i drugiej odpowiednio się przygotowywała: przez 2 lata i 2 miesiące stosowała dietę umożliwiającą utrzymanie stężenia Phe $\mathrm{w}$ rekomendowanym przedziale $120-360 \mu \mathrm{mol} / \mathrm{l}$ (2-6 mg\%). ${ }^{6} \mathrm{~W}$ momencie zajścia $\mathrm{W}$ obie ciąże pozostawała w stanie wyrównania metabolicznego (tabela 1), przy czym wskaźnik BMI przed ciążą był mniejszy od rekomendowanego $\left(18,5-24,9^{12}\right)$, szczególnie w drugiej ciąży. W każdym tygodniu ciąży oznaczenia stężenia Phe we krwi wykonywano 2 lub 3 razy i zachęcano chorą do przesyłania jadłospisów nie rzadziej niż 2-krotnie, co umożliwiało szybkie dostosowywanie podaży Phe do dynamicznie zmieniającej się tolerancji tego aminokwasu.

Stosunek masy urodzeniowej potomstwa do przyrostu masy ciała u ciężarnej w obu ciążach był podobny (tabela 1). Porody zdrowych dzieci nastąpiły w 40. tygodniu 
Tabela 1. Charakterystyka 2 ciąż pojedynczych u pacjentki chorej na PKU

Table 1. Clinical data on 2 singleton pregnancies in the presented PKU patient resulting in live births

\begin{tabular}{|c|c|c|c|}
\hline \multirow{2}{*}{\multicolumn{2}{|c|}{ Dane }} & \multicolumn{2}{|c|}{ Genotyp p.R408W/p.R408W } \\
\hline & & pierwsza ciąża & druga ciąża \\
\hline \multicolumn{2}{|c|}{$\begin{array}{l}\text { Wiek pacjentki w momencie } \\
\text { zajścia w ciążę [lata] }\end{array}$} & 25 & 27 \\
\hline \multicolumn{2}{|c|}{ Procedura wspomagania in vitro } & nie & nie \\
\hline \multicolumn{2}{|l|}{ Palenie w ciąży } & nie & nie \\
\hline \multicolumn{2}{|c|}{ Masa ciała przed ciążą [kg] } & 49,9 & 46,6 \\
\hline \multicolumn{2}{|c|}{ BMI przed ciążą [kg/m²] } & 17,8 & 16,6 \\
\hline \multicolumn{2}{|c|}{ Przyrost masy ciała w ciąży [kg] } & 19,1 & 19,4 \\
\hline \multicolumn{2}{|c|}{ BMI przed porodem [kg/m²] } & 24,6 & 23,6 \\
\hline \multicolumn{2}{|c|}{$\begin{array}{l}\text { Przyrost masy ciała w I trymestrze } \\
\text { ciąży }[\mathrm{kg}]\end{array}$} & 3,1 & 3,4 \\
\hline \multicolumn{2}{|c|}{ BMI w I trymestrze ciąży [kg/m²] } & 18,90 & 17,85 \\
\hline \multicolumn{2}{|c|}{$\begin{array}{l}\text { Stosunek masy urodzeniowej } \\
\text { potomstwa do przyrostu masy } \\
\text { ciała ciężarnej [\%] }\end{array}$} & 19 & 18 \\
\hline \multicolumn{2}{|c|}{ 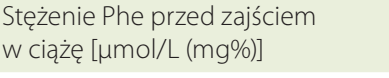 } & $\begin{array}{l}34,2 \\
(0,57)\end{array}$ & $\begin{array}{l}124,2 \\
(2,07)\end{array}$ \\
\hline \multicolumn{2}{|c|}{$\begin{array}{l}\text { Wprowadzenie diety } \\
\text { niskofenyloalaninowej przed } \\
\text { ciążą }\end{array}$} & tak & tak \\
\hline \multicolumn{2}{|l|}{ Preparat leczniczy } & $\begin{array}{l}\text { XP Maxamum, } \\
\text { Milupa PKU3 } \\
\text { tempora }\end{array}$ & XP Maxamum \\
\hline \multicolumn{2}{|c|}{$\begin{array}{l}\text { \% wyników oznaczeń stężenia Phe } \\
>360 \text { mol/L (6 mg\%) w całej } \\
\text { ciąży }\end{array}$} & 14 & 3 \\
\hline \multicolumn{2}{|c|}{$\begin{array}{l}\text { \% wyników oznaczeń stężenia Phe } \\
<120 \text { Hmol/L ( } 2 \text { mg\%) w całej } \\
\text { ciąży }\end{array}$} & 37 & 29 \\
\hline \multirow{5}{*}{$\begin{array}{l}\text { Dobowa podaż } \\
\text { białka z preparatu } \\
\text { leczniczego }[\mathrm{g}]\end{array}$} & $14 \mathrm{Hbd}$ & 58,5 & 58,5 \\
\hline & $28 \mathrm{Hbd}$ & 79,5 & 73 \\
\hline & $34 \mathrm{Hbd}$ & 86,5 & 78 \\
\hline & $38 \mathrm{Hbd}$ & 93,5 & 87,75 \\
\hline & $39 \mathrm{Hbd}$ & 93,5 & 87,75 \\
\hline \multirow{5}{*}{$\begin{array}{l}\text { Dobowa podaż } \\
\text { energii [kcal] }\end{array}$} & $14 \mathrm{Hbd}$ & 2104-2656 & $1567-2231$ \\
\hline & $28 \mathrm{Hbd}$ & $2505-3015$ & 1978-2860 \\
\hline & $34 \mathrm{Hbd}$ & $2273-3140$ & $1231-3083$ \\
\hline & $38 \mathrm{Hbd}$ & 3307-3519 & 2443-3220 \\
\hline & $39 \mathrm{Hbd}$ & 2729-3054 & 2546-2910 \\
\hline
\end{tabular}
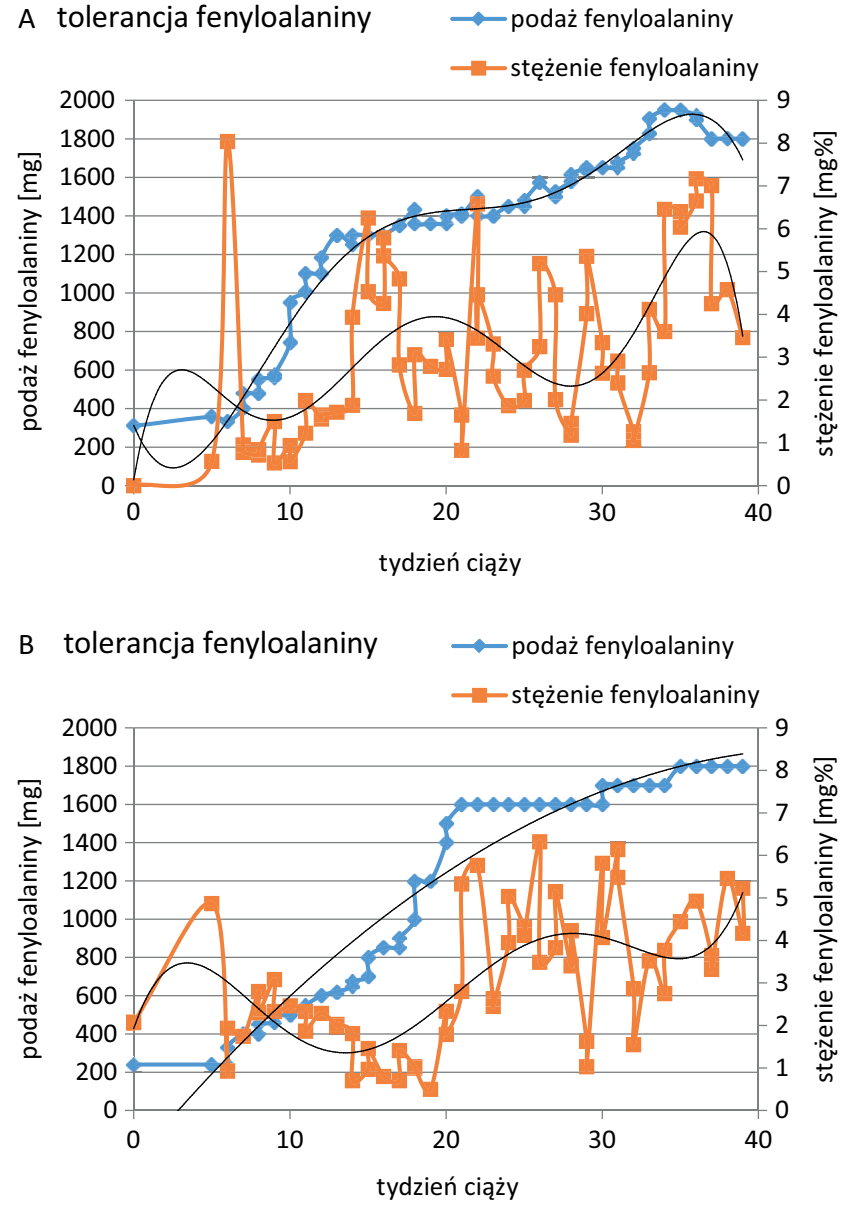

Ryc. 1. Tolerancja Phe w ciąży pierwszej (A) i drugiej (B) u chorej na PKU

Fig. 1. Phe tolerance during the first (A) and second (B) pregnancy of the presented PKU patient

ciąży (tabela 2). Urodzeniowe masy ciała noworodków mieściły się w rekomendowanym przez WHO przedziale 3100-3600 g. ${ }^{13}$ Stężenia Phe we krwi oraz tolerancję Phe przedstawiono na ryc. 1. Stosunek tolerancji Phe do masy ciała ciężarnej był podobny (w obu ciążach) poza pierwszymi kilkunastoma tygodniami (ryc. 1, tabela 3). Stosunek tolerancji Phe do masy urodzeniowej oraz estymowanej masy płodu przedstawiono w tabeli 4. W III trymestrze wystąpił tylko niewielki wzrost tolerancji Phe, odpowiednio 30,2\% i 12,5\% w pierwszej i drugiej ciąży (tabela 5). Przez całą pierwszą i drugą ciążę tolerancja Phe wzrosła maksymalnie odpowiednio: 5,5- i 6,5-krotnie

Tabela 2. Zestawienie pomiarów urodzeniowych potomstwa pacjentki chorej na PKU

Table 2. Birth measurements for completed pregnancies of the presented PKU patient

\begin{tabular}{|c|c|c|c|c|c|c|c|c|c|}
\hline Ciąża & $\begin{array}{l}\text { Tydzień } \\
\text { ciąży }\end{array}$ & Płeć & $\begin{array}{c}\text { Masa ciała } \\
{\left[\text { [g; percentyl] }^{\mathrm{a}}\right.}\end{array}$ & $\begin{array}{l}\text { Długość } \\
\text { ciała [cm; } \\
\text { percentyl] }\end{array}$ & $\begin{array}{l}\text { Obwód głowy } \\
\text { [cm; percentyl] }\end{array}$ & $\begin{array}{l}\text { Punktacja } \\
\text { Apgar }\end{array}$ & $\begin{array}{l}\text { Wady wrodzone, } \\
\text { cechy dysmorfii }\end{array}$ & $\begin{array}{c}\text { Phe w przesiewie } \\
\text { noworodków } \\
{[\mu \mathrm{mol} / \mathrm{L}]}\end{array}$ & $\begin{array}{c}\text { Status } \\
\text { chorego } \\
\text { na PKU }\end{array}$ \\
\hline Pierwsza & 40 & żeńska & $3600 ;>50$ & $55 ;>97$ & $34 ;<50$ & 10 & nie & 80,4 (1,34 mg\%) & nie \\
\hline Druga & 40 & męska & $3450 ;<50$ & $55 ;<97$ & $33 ; 10$ & 10 & nie & 67,2 (1,12 mg\%) & nie \\
\hline
\end{tabular}

a Według standardów WHO. 
Tabela 3. Szacunkowa tolerancja Phe i jej stosunek do masy ciała ciężarnej w pierwszej i drugiej ciąży

Table 3. Estimated Phe tolerance and its ratio to weight of the presented pregnant woman in the first and second pregnancy

\begin{tabular}{|c|c|c|c|c|c|c|}
\hline \multirow{2}{*}{$\begin{array}{l}\text { Wiek ciąży } \\
\text { [tygodnie] }\end{array}$} & \multicolumn{3}{|c|}{ Pierwsza ciąża } & \multicolumn{3}{|c|}{ Druga ciąża } \\
\hline & $\begin{array}{l}\text { Stężenie Phe } \\
{[\mu \mathrm{mol} / \mathrm{L}]}\end{array}$ & $\begin{array}{c}\text { Tolerancja Phe } \\
{[\mathrm{mg}]}\end{array}$ & $\begin{array}{c}\mathrm{Phe} / \mathrm{masa} \text { ciałac } \\
{[\mathrm{mg} / \mathrm{kg}]}\end{array}$ & $\begin{array}{l}\text { Stężenie Phe } \\
\text { [ } \mu \mathrm{mol} / \mathrm{L}]\end{array}$ & $\begin{array}{c}\text { Tolerancja Phe } \\
{[\mathrm{mg}]}\end{array}$ & $\begin{array}{c}\text { Phe } / \mathrm{masa} \text { ciałac } \\
{[\mathrm{mg} / \mathrm{kg}]}\end{array}$ \\
\hline 14 & $\begin{array}{c}306 \\
(236 ; 375)^{\mathrm{a}}\end{array}$ & $\begin{array}{c}1250 \\
(1200-1300)^{b}\end{array}$ & $\begin{array}{c}23,6 \\
(22,6-24,5)\end{array}$ & $\begin{array}{c}76 \\
(109-42)^{a}\end{array}$ & $\begin{array}{c}672 \\
(643-700)^{b}\end{array}$ & $\begin{array}{c}13,44 \\
(12,9-14)\end{array}$ \\
\hline 28 & $\begin{array}{c}164 \\
(88 ; 241)^{\mathrm{a}}\end{array}$ & $\begin{array}{c}1615 \\
(1580-1650)^{b}\end{array}$ & $\begin{array}{c}25,6 \\
(25,1 ; 26,2)\end{array}$ & $\begin{array}{c}228 \\
(204 ; 254)^{\mathrm{a}}\end{array}$ & 1600 & 25,8 \\
\hline $39^{d}$ & 336 & 1800 & 26,1 & $\begin{array}{c}282 \\
(314 ; 250)^{\mathrm{a}}\end{array}$ & 1800 & 27,3 \\
\hline
\end{tabular}

a Średnie z co najmniej 2 oznaczeń.

b Uśredniona rekonstrukcja co najmniej 2 jadłospisów.

Stosunek tolerowanego spożycia Phe do aktualnej masy ciała ciężarnej.

d Przedostatni tydzień ciąży.

(tabela 5). Pomiędzy 33. a 36. tygodniem ciąży tolerancja Phe była wyższa o ok. 7-15\% w pierwszej ciąży niż w drugiej. Od 37. tygodnia nie obserwowano różnic w tolerancji Phe w obu ciążach, wyrażonej również jako stosunek do estymowanych mas płodów (ryc. 1, tabela 4).

Po urodzeniu pierwszego dziecka pogorszyła się kontrola stężenia Phe, natomiast po drugiej ciąży pacjentka praktycznie zrezygnowała ze stosowania leczniczej diety.

\section{Omówienie}

U przedstawionej chorej występowała w układzie homozygotycznym najczęstsza w populacji polskiej mutacja (p.R408W) genu PAH, kodującego enzym hydroksylazę fenyloalaninową. ${ }^{14}$ Wiek zajścia w obie ciąże przypadł na optymalny okres życia do podejmowania prokreacji ${ }^{15,16}$ i nie występowało obciążenie nikotynizmem. Zgodnie $\mathrm{z}$ rekomendacjami dietę niskofenyloalaninową stosowano nie tylko w ciąży, ale i w okresie prekoncepcyjnym. ${ }^{6,17-19}$ Mimo mniejszej tolerancji Phe na początku ciąży drugiej końcowa wartość tego parametru, w tym także po przeliczeniu na masę ciężarnej oraz płodu, była prawie identyczna jak w ciąży pierwszej. W III trymestrze nie nastąpił radykalny wzrost tolerancji Phe, czego nie można w obu przypadkach tłumaczyć PKU u płodu, jak to postulowali Kohlschütter et al. ${ }^{7}$ Podkreślenia wymaga obserwacja ledwie 12,5\% przyrostu tolerancji Phe w III trymestrze drugiej ciąży w zestawieniu tylko z 20\% przyrostem w pierwszej ciąży, pod warunkiem, że uwzględniamy wyliczenia tolerancji Phe w ostatnich tygodniach ciąży (37-39; ryc. 1), a nie jak w tabeli 5 maksymalną odnotowaną wartość z 34. tygodnia ciąży. Mały wzrost tolerancji Phe pod koniec ciąży u opisanej ciężarnej, u której nie zaobserwowano istotnej resztkowej aktywności enzymu hydroksylazy fenyloalaninowej mogącej podlegać stymulacji, ${ }^{20} \mathrm{w}$ połączeniu z urodzeniem o czasie dojrzałych zdrowych noworodków (o prawidłowej masie ciała i ocenionych na 10 punktów w skali Apgar) pobudza do pogłębionej dyskusji o roli wątroby płodu w wyrównaniu metabolicznym chorej na fenyloketonurię w ciąży. Warto dodatkowo zauważyć, że w III trymestrze drugiej ciąży bezwzględny wzrost tolerancji Phe wyniósł 200 mg, czyli porównywalnie jak w analogicznym okresie ciąży (genotyp ciężarnej p.R408W/p.R261Q) z płodem chorym na PKU (genotyp p.R408W/p.R408W) opisanym przez Kohlschütter et al. ${ }^{7} \mathrm{~W}$ retrospektywnych pracach poświęconych zależnościom między charakterystyką zmienności stężenia Phe a przebiegiem ciąży w PKU nie uwzględniano genotypu kobiet. ${ }^{19}$ Widaman i Azen ${ }^{21}$ stwierdzili zależność nasilenia zmienności stężenia Phe m.in. od genotypu i wieku ciężarnych chorych na PKU leczonych dietetycznie. U opisanej przez autorów niniejszego artykułu pacjentki, mimo prawidłowych stężeń Phe w okresie okołokoncepcyjnym, niedobór masy ciała przed drugą ciążą współwystępował z wolniejszym wzrostem tolerancji Phe na początku ciąży. Dotychczas jako istotny czynnik korzystnie wpływający na tolerancję Phe w I trymestrze ciąży wskazywano rozpoczęcie stosowania leczniczej diety w okresie prekoncepcyjnym w porównaniu do jej nawet niezwłocznego wdrażania dopiero po zajściu w ciążę. U osób zdrowych przedkoncepcyjny BMI niemieszczący się w zalecanej normie jest czynnikiem ryzyka nieprawidłowego przebiegu ciąży, w tym zaburzeń organogenezy i wzrastania płodu, oraz postnatalnych zaburzeń neurorozwojowych. ${ }^{22-24}$ Sygnalizowano także możliwość oddziaływania na tolerancję Phe dotychczas niepoznanych czynników łożyskowych i matczynych. ${ }^{19}$ Przypuszczalnie utworzenie baz danych uwzględniających genotypy i dane antropometryczne ciężarnych oraz szczegółowe zapisy zmian tolerancji Phe umożliwi poznanie regulacji wzrostu tolerancji Phe u ciężarnych pacjentek chorych na PKU.

Podobnie jak hiperfenyloalaninemia, nadmierne ograniczenie podaży Phe i małe stężenia tego aminokwasu we krwi ciężarnej stanowią czynnik ryzyka wewnątrzmacicznego zahamowania wzrastania płodu. ${ }^{25}$ Mimo wysokiego odsetka oznaczeń stężenia Phe $<120$ mol/l ( $<2$ mg\%) urodzeniowa długość i masa ciała noworodków z obu ciąż była prawidłowa lub przekraczała 97. percentyl. Relatywnie mały urodzeniowy obwód głowy chłopca z drugiej 
Tabela 4. Szacunkowa tolerancja Phe w pierwszej i drugiej ciąży z uwzględnieniem masy ciała płodów

Table 4. Estimated Phe tolerance and its ratio to fetal weight in the first and second pregnancy

\begin{tabular}{|c|c|c|c|c|c|c|}
\hline \multirow{2}{*}{$\begin{array}{l}\text { Tydzień } \\
\text { ciąży }\end{array}$} & \multicolumn{3}{|c|}{ Pierwsza ciąża } & \multicolumn{3}{|c|}{ Druga ciąża } \\
\hline & $\begin{array}{c}\text { Stężenie Phe }{ }^{\mathrm{a}} \\
{[\mu \mathrm{mol} / \mathrm{L}(\mathrm{mg} \%)]}\end{array}$ & $\begin{array}{c}\text { Tolerancja Phe }{ }^{b} \\
{[\mathrm{mg}]}\end{array}$ & $\begin{array}{c}\text { Phe/masa płoduc } \\
{[\mathrm{mg} / \mathrm{kg}]}\end{array}$ & $\begin{array}{l}\text { Stężenie Phe }{ }^{a} \\
\text { [mg\%] }\end{array}$ & $\begin{array}{c}\text { Tolerancja Phe }{ }^{b} \\
{[\mathrm{mg}]}\end{array}$ & $\begin{array}{c}\text { Phe/masa płoduc } \\
{[\mathrm{mg} / \mathrm{kg}]}\end{array}$ \\
\hline 22 & $\begin{array}{c}237,3(3,96) \\
207 ; 267,6 \\
(3,45 ; 4,46)\end{array}$ & $\begin{array}{c}1450 \\
(1400-1500)\end{array}$ & $\begin{array}{c}2900 \\
(2800-3000)\end{array}$ & $346,2(5,77)$ & 1600 & 2909 \\
\hline 25 & $\begin{array}{c}178,8(2,98) \\
162 ; 195 \\
(2,7 ; 3,25)\end{array}$ & $\begin{array}{c}1465 \\
(1450-1480)\end{array}$ & $\begin{array}{c}2092,85 \\
(2071,4-2114,3)\end{array}$ & $\begin{array}{c}252(4,2) \\
258,6 ; 247,2 \\
(4,31 ; 4,12)\end{array}$ & 1600 & 2133,3 \\
\hline 29 & $\begin{array}{c}261(4,35) \\
321,6 ; 200,4 \\
(5,36 ; 3,34)\end{array}$ & $\begin{array}{c}1636 \\
(1622-1650)\end{array}$ & $\begin{array}{c}1422,6 \\
(1410,4-1434,8)\end{array}$ & $\begin{array}{c}79,8(1,33) \\
97,2 ; 61,8 \\
(1,62 ; 1,03)\end{array}$ & 1600 & 1333,3 \\
\hline 30 & $\begin{array}{l}166,2(2,77) \\
157,8 ; 174,6 \\
(2,63 ; 2,91)\end{array}$ & 1650 & 1269,2 & $\begin{array}{c}294(4,9) \\
349,2 ; 244,2 \\
(5,82 ; 4,07)\end{array}$ & $\begin{array}{c}1650 \\
(1600-1700)\end{array}$ & $\begin{array}{c}1178,6 \\
(1142,9-1214,3)\end{array}$ \\
\hline 31 & $\begin{array}{c}109,8(1,83) \\
75,6 ; 144 \\
(1,26 ; 2,4)\end{array}$ & $\begin{array}{c}1675 \\
(1650-1700)\end{array}$ & $\begin{array}{c}1116,7 \\
(1100-970,9-1133,3)\end{array}$ & $\begin{array}{c}348(5,8) \\
368,4 ; 329,4 \\
(6,14 ; 5,49)\end{array}$ & 1700 & 1062,5 \\
\hline 32 & $\begin{array}{c}166,2(2,77) \\
174 ; 157,8 \\
(2,9 ; 2,63)\end{array}$ & $\begin{array}{c}1725 \\
(1700-1751)\end{array}$ & $\begin{array}{c}1014,7 \\
(1000-1030)\end{array}$ & $\begin{array}{c}132,6(2,21) \\
172,2 ; 93 \\
(2,87 ; 1,55)\end{array}$ & 1700 & 944,4 \\
\hline 33 & $\begin{array}{c}231,6(3,86) \\
247,2 ; 216 \\
(4,12 ; 3,6)\end{array}$ & $\begin{array}{c}1830 \\
(1753-1908)\end{array}$ & $\begin{array}{c}963,2 \\
(922,6-1004,2)\end{array}$ & $211,2(3,52)$ & 1700 & 850 \\
\hline 34 & $385,8(6,43)$ & $\begin{array}{c}1950 \\
(1948-1953)\end{array}$ & $\begin{array}{c}928,6 \\
(927,6-930)\end{array}$ & $\begin{array}{c}195,6(3,26) \\
165 ; 226,2 \\
(2,75 ; 3,77)\end{array}$ & 1700 & 755,5 \\
\hline 35 & $\begin{array}{l}381(6,35) \\
362,4 ; 399 \\
(6,04 ; 6,65)\end{array}$ & 1950 & 829,8 & $266,4(4,44)$ & 1800 & 720 \\
\hline 36 & $\begin{array}{c}425,4(7,09) \\
430,2 ; 420,6 \\
(7,17 ; 7,01)\end{array}$ & $\begin{array}{c}1924,5 \\
(1899-1950)\end{array}$ & $\begin{array}{c}740,2 \\
(730,4-750)\end{array}$ & $295,8(4,93)$ & 1800 & 666,7 \\
\hline 37 & $\begin{array}{c}264(4,4) \\
255 ; 274,8 \\
(4,25 ; 4,58)\end{array}$ & $\begin{array}{c}1800 \\
(1799-1801)\end{array}$ & $\begin{array}{c}631,6 \\
(631,2-631,9)\end{array}$ & $\begin{array}{c}209,4(3,49) \\
219 ; 199,2 \\
(3,65 ; 3,32)\end{array}$ & 1800 & 610 \\
\hline 38 & $207,6(3,46)$ & $\begin{array}{c}1801,5 \\
(1801-1802)\end{array}$ & $\begin{array}{c}590,65 \\
(590,5-590,8)\end{array}$ & $327,6(5,46)$ & 1800 & 571,4 \\
\hline 39 & $336(5,6)$ & 1800 & 553,8 & $\begin{array}{c}282(4,7) \\
313,8 ; 250,2 \\
(5,23 ; 4,17)\end{array}$ & 1800 & 537,3 \\
\hline
\end{tabular}

árednie z co najmniej 2 oznaczeń.

b Uśredniona rekonstrukcja co najmniej 2 jadłospisów.

c Stosunek tolerowanego spożycia Phe do estymowanej masy płodu.

Tabela 5. Wzrost tolerancji Phe w różnych okresach ciąży

Table 5. Increase in Phe tolerance during the course of pregnancy

\begin{tabular}{|c|c|c|c|c|c|c|c|c|}
\hline \multirow{3}{*}{ Ciąża } & \multicolumn{8}{|c|}{ Wzrost tolerancji fenyloalaniny } \\
\hline & \multicolumn{2}{|c|}{ I trymestr } & \multicolumn{2}{|c|}{ II trymestr } & \multicolumn{2}{|c|}{ III trymestr } & \multicolumn{2}{|c|}{ cała ciąża } \\
\hline & $\mathrm{mg}$ & $\%$ & $\mathrm{mg}$ & $\%$ & $\mathrm{mg}$ & $\%$ & $\mathrm{mg}$ & $\%$ \\
\hline Pierwsza & $\begin{array}{c}1000 \\
300 \rightarrow 1300\end{array}$ & 333,3 & $\begin{array}{c}400 \\
1200 \rightarrow 1600\end{array}$ & 33,3 & $\begin{array}{c}453 \\
1500 \rightarrow 1953\end{array}$ & 30,2 & $\begin{array}{c}1653 \\
300 \rightarrow 1953\end{array}$ & 551 \\
\hline Druga & $\begin{array}{c}410 \\
240 \rightarrow 650\end{array}$ & 170,8 & $\begin{array}{c}957 \\
643 \rightarrow 1600\end{array}$ & 148,8 & $\begin{array}{c}200 \\
1600 \rightarrow 1800\end{array}$ & 12,5 & $\begin{array}{c}1560 \\
240 \rightarrow 1800\end{array}$ & 650 \\
\hline
\end{tabular}

Strzałką oznaczono najmniejsze i największe wyliczenie tolerancji fenyloalaniny, nie zawsze pokrywające się z wyliczeniami dokładnie z początku i końca danego trymestru (ryc. 1). 
ciąży (ok. 10. percentyla) nie był powiązany z wysokim odsetkiem oznaczeń Phe >360 $\mu \mathrm{mol} / \mathrm{l}$ (>6 mg\%). Małogłowie, wrodzone wady serca oraz zaburzony rozwój intelektualny stanowią główne objawy zespołu fenyloketonurii matczynej. ${ }^{17,18,25,26}$ Matalon et al. ${ }^{27}$ wykazali korelację między małym przyrostem (<70\% rekomendowanego) masy ciała ciężarnej chorej na PKU a małogłowiem u potomstwa.

Niezmiennie dla wszystkich kobiet chorych na PKU oraz u których rozpoznano inne postacie hiperfenyloalaninemii w wieku rozrodczym rekomenduje się edukację dotyczącą skutków nieunormowanych stężeń Phe dla płodu już od okresu prekoncepcyjnego i sposobów przygotowania się do ciąży. ${ }^{6,19,28}$

\section{Wnioski}

Odmienna dynamika wzrostu tolerancji Phe na początku obu ciąż sugeruje istotny wpływ czynników środowiskowych w jej kształtowaniu. Częste oznaczenia stężenia Phe stanowią podstawowe narzędzie opieki nad ciężarną chorą na PKU.

Powtarzający się brak radykalnego zwiększenia tolerancji Phe w III trymestrze u opisanej pacjentki bez istotnej resztkowej aktywności enzymu hydroksylazy fenyloalaninowej nie popiera tezy o fundamentalnym udziale wątroby płodu niechorującego na PKU w homeostazie Phe w ciąży zaawansowanej.

Jedno z największych osiągnięć medycyny zapobiegawczej, jakim jest wprowadzenie obligatoryjnego badania przesiewowego noworodków w kierunku PKU, skutkuje koniecznością prowadzenia badań nad metodami opieki nad pacjentami zmagającymi się z tą chorobą w wieku prokreacyjnym.

\section{ORCID iDs}

Joanna Żółkowska (1) https://orcid.org/0000-0002-9611-9860 Kamil Konrad Hozyasz (1) https://orcid.org/0000-0001-8606-2509

\section{References}

1. Resta R. Generation $n+1$ : Projected numbers of babies born to women with PKU compared to babies with PKU in the United States in 2009. Am J Med Genet. 2012;158A(5):1118-1123. doi:10.1002/ajmg.a.35312

2. Guthrie R. Maternal PKU: A continuing problem. Am J Public Health. 1988;78(7):771. https://www.ncbi.nlm.nih.gov/pmc/articles /PMC1350330/?page=1. Dostęp 12.06.2019.

3. Prick BW, Hop WC, Duvekot JJ. Maternal phenylketonuria and hyperphenylalaninemia in pregnancy: Pregnancy complications and neonatal sequelae in untreated and treated pregnancies. Am J Clin Nutr. 2012;95(2):374-382. doi:10.3945/ajcn.110.009456

4. Lee PJ, Ridout D, Walter JH, Cockburn F. Maternal phenylketonuria: Report from the United Kingdom Registry 1978-97. Arch Dis Child. 2005;90(2):143-146. doi:10.1136/adc.2003.037762

5. Brenton DP, Lilburn M. Maternal phenylketonuria. A study from the United Kingdom. Eur J Pediatr. 1996;155(supl 1):S177-S180.

6. van Wegberg AM, MacDonald A, Ahring K, et al. The complete European guidelines on phenylketonuria: Diagnosis and treatment. Orphanet J Rare Dis. 2017;12:162. doi:10.1186/s13023-017-0685-2

7. Kohlschütter B, Ellerbrok M, Merkel M, et al. Phenylalanine tolerance in three phenylketonuric women pregnant with fetuses of different genetic PKU status. J Inherit Metab Dis. 2009;32(supl 1):S1-S4. doi: 10.1186/s13023-017-0685-2

8. Wang Y, Li SR, Zeng ZG, Du WG. Maternal food availability affects offspring performance and survival in a viviparous lizard. Funct Ecol. 2017;31:1950-1956. doi:10.1111/1365-2435.12903

9. Lowe WL Jr, Bain JR, Nodzenski M, et al. Maternal BMI and glycemia impact the fetal metabolome. Diabetes Care. 2017;40(7):902910. doi:10.2337/dc16-2452

10. Hellmuth $\mathrm{C}$, Lindsay $\mathrm{KL}$, Uhl $\mathrm{O}$, et al. Association of maternal prepregnancy BMI with metabolomic profile across gestation. Int J Obes (Lond). 2017;41(1):159-169. doi:10.1038/ijo.2016.153

11. Jensen VF, Mølck AM, Lykkesfeldt J, Bøgh IB. Effect of maternal hypoglycaemia during gestation on materno-foetal nutrient transfer and embryo-foetal development: Evidence from experimental studies focused primarily on the rat. Reprod Toxicol. 2018;77:1-24. doi: 10.1016/j.reprotox.2018.01.007

12. Siega-Riz AM, Deierlein A, Stuebe A. Implementation of the New Institute of Medicine Gestational Weight Gain Guidelines. J Midwifery Womens Health. 2010;55(6):512-519. doi:10.1016/j.jmwh.2010 .04 .001

13. Maternal antropometry and pregnancy outcomes: A WHO collaborative study. Bull World Health Organ. 1995;73(supl 1):1-98.

14. Bik-Multanowski K, Kałużny Ł, Mozrzymas R, et al. Molecular genetics of PKU in Poland and potential impact of mutations on $\mathrm{BH} 4$ responsiveness. Acta Biochim Pol. 2013;60(4):613-616. http://www.actabp .pl/pdf/4_2013/613.pdf. Dostęp 12.06.2019.

15. Cabrera-Leon A,Lopez-VillaverdeV,RuedaM,Moya-GarridoMN.Calibrated prevalence of infertility in 30-to 49-years-old women according to different approaches: A cross-sectional population-based study. Hum Reprod. 2015;30(11):2677-2688. doi:10.1093/humrep /dev226

16. Deatsman S, Vasilopoulos T, Rhoton-Vlasak A. Age and fertility: A study of patient awareness. JBRA Assist Reprod. 2016;20(3):99-106. doi:10.5935/1518-0557.20160024

17. Didycz B, Domagała L, Pietrzyk JJ. Zespół fenyloketonurii matczynej - problem nadal aktualny. Przegl Lek. 2009;66:4-10. http: //www.wple.net/plek/numery_2009/numer-1-2-2009/4-10.pdf. Dostęp 12.06.2019.

18. Paprocka J, Jamroz E, Wiktor M, Marszał E. Maternal phenylketonuria. Wiad Lek. 2009;62(1):11-17.

19. Maillot F, Lilburn M, Baudin J, Morley DW, Lee PJ. Factors influencing outcomes in the offspring of mothers with phenylketonuria during pregnancy: The importance of variation in maternal blood phenylalanine. Am J Clin Nutr. 2008;88(3):700-705. doi:10.1093/ajcn /88.3.700

20. Guldberg P, Rey F, Zschocke J, et al. A European Multicenter Study of Phenylalanine Deficiency: Classification of 105 mutations and a general system for genotype-based prediction of metabolic phenotype. Am J Hum Genet. 1998;63(1):71-79. doi:10.1086/301920

21. Widaman KF, Azen C. Relation of prenatal phenylalanine exposure to infant and childhood cognitive outcomes: Results from the International Maternal PKU Collaborative Study. Pediatrics. 2003;112 (6 Pt 2):1537-1543. https://link.springer.com/article/10.1023/B:BOLI .0000045758.86492.54. Dostęp 12.06.2019.

22. Siega-Riz M, Adair LS, Hobel CJ. Maternal underweight status and inadequate rate of weight gain during the third trimester of pregnancy increases the risk of preterm delivery. J Nutr. 1996;126(1):146-153. doi:10.1093/jn/126.1.146

23. Hinkle SN, Schieve LA, Stein AD, Swan DW, Ramakrishnan U, Sharma U. Associations between maternal prepregnancy body mass index and child neurodevelopment at 2 years of age. Int J Obes (Lond). 2012;36(10):1312-1319. doi:10.1038/ijo.2012.143

24. Jeric M, Roje D, Medic N, Strinic T, Mestrovic Z, Vulic M. Maternal pre-pregnancy underweight and fetal growth in relations to Institute of Medicine recommendations for gestational weight gain. Early Hum Dev. 2013;89(5):277-281. doi:10.1016/j.earlhumdev .2012.10.004

25. Teissier R, Nowak E, Assoun M, et al; Association Française pour le Dépistage et la Prévention des Handicaps de l'Enfant. Maternal phenylketonuria: Low phenylalaninemia might increase the risk of intra uterine growth retardation. J Inherit Metab Dis. 2012;35(6):993-999. doi:10.1007/s10545-012-9491-0 
26. Koch R, Gross Friedman EG, Wenz E, Jew K, Crowley C, Donnell G. Maternal phenylketonuria. J Inher Metab Dis. 1986;9(supl 2):159-168. https://link.springer.com/chapter/10.1007/978-94-009-4131-1_20. Dostęp 12.06.2019.

27. Matalon KM, Acosta PB, Azen C. Role of nutrition in pregnancy with phenylketonuria and birth defects. Pediatrics. 2003;112(6 Pt 2): 1534-1536. https://pediatrics.aappublications.org/content/112/Supplement 4/1534. Dostęp 12.06.2019.

28. American Academy of Pediatrics, Committee on Genetics. Maternal phenylketonuria. Pediatrics. 2001;107:427-428. https://pediatrics. aappublications.org/content/122/2/445. Dostęp 12.06.2019. 